\title{
Screening for hydrogen-producing strains of green microalgae in phosphorus or sulphur deprived medium under nitrogen limitation
}

\author{
Piyawat Pongpadung ${ }^{\mathrm{a}, \mathrm{b}}$, Jianguo Liu ${ }^{\mathrm{c}}$, Kittisak Yokthongwattana ${ }^{\mathrm{d}}$, Sombun Techapinyawat ${ }^{\mathrm{b}, \mathrm{e}}$, \\ Niran Juntawong ${ }^{\mathrm{a}, \mathrm{b}, \mathrm{e}, *}$ \\ ${ }^{a}$ Research Centre for Photosynthetic Pigments and Secondary Metabolites, Faculty of Science, \\ Kasetsart University, Bangkok 10900 Thailand \\ b Bioscience Program, Faculty of Science, Kasetsart University, Bangkok 10900 Thailand \\ c Institute of Oceanology, Chinese Academy of Sciences, Qingdao, Shandong 266071 China \\ ${ }^{d}$ Department of Biochemistry and Centre for Excellence in Protein Structure and Function, \\ Faculty of Science, Mahidol University, Bangkok 10400 Thailand \\ e Department of Botany, Faculty of Science, Kasetsart University, Bangkok 10900 Thailand
}

*Corresponding author, e-mail: fscinrj@ku.ac.th

Received 16 Oct 2014

Accepted 17 May 2015

\begin{abstract}
Hydrogen gas, one of the best candidates for clean and renewable energy, can be produced by microalgae that can use solar energy to cause photolysis of water. This study screened $\mathrm{H}_{2}$-producing indigenous green microalgae under sulphur (S-) deprivation, simultaneous nitrogen (N-) limitation and S-deprivation, or simultaneous N-limitation and phosphorus (P-) deprivation. Sequences of 18S rDNA and ITS in conjunction with morphological characteristics were used to identify the algae. We report that Chlorella lewinii, Micractinium sp., Coelastrella sp., and Monoraphidium sp. have the ability to produce $\mathrm{H}_{2}$. The increase in $\mathrm{H}_{2}$ photoproduction when $\mathrm{N}$ is limited seems to be a universal phenomenon in most tested strains of Chlorella, in all strains of Chlamydomonas, but in no strain of Coelastrella, Micractinium, or Scenedesmus. Chlorella sorokiniana KU204 produced $\mathrm{H}_{2}(46 \mathrm{ml} / \mathrm{l})$ under S-deprivation. This strain exhibited the highest $\mathrm{H}_{2}$-producing ability $\left(1.30 \mathrm{ml} \mathrm{l}^{-1} \mathrm{~h}^{-1}\right)$ and accumulated up to $90 \mathrm{ml} / 1$ under simultaneous $\mathrm{N}$-limitation and S-deprivation. Interestingly, C. sorokiniana KU204 could also produce $\mathrm{H}_{2}$ under simultaneous $\mathrm{N}$-limitation and P-starvation ( $69 \mathrm{ml} / \mathrm{l})$. The induction time to reach an anoxic state by most tested strains of Chlorella, but not Chlamydomonas, was shorter under simultaneous N-limitation and S-deprivation than under S-deprivation. In addition, those strains of Chlorella exhibited high $\mathrm{H}_{2}$ photoproduction under simultaneous N-limitation and S-deprivation. A few Chlorella strains were unable to reach an anoxic state during the experiment. However, such regularity is not found in Chlamydomonas. The results indicate that the mechanism of $\mathrm{H}_{2}$ photoproduction in Chlorella may differ from that in Chlamydomonas.
\end{abstract}

KEYWORDS: hydrogen production, green algae, sulphur deprivation, phosphorus deprivation

\section{INTRODUCTION}

Renewable energy is being actively sought worldwide to replace the declining sources of fossil fuels. Hydrogen gas is considered to be one of the best candidates for alternative clean energy ${ }^{1} . \mathrm{H}_{2}$ can be produced by microalgae that have an ability to capture solar energy and convert it into chemical energy. Hydrogen production under anaerobic conditions was first reported for the unicellular green alga Scenedesmus obliquus ${ }^{2}$. $\mathrm{H}_{2}$ was only produced for a few minutes and then the yield dropped. A system that maintains the capacity of evolving large amounts of $\mathrm{H}_{2}$ for several days under S-deprivation in the green alga Chlamydomonas reinhardtii was later developed ${ }^{3}$. S-deprivation reduced the photosynthetic $\mathrm{O}_{2}$-evolving machineries in the algal cells leading to intracellular anaerobiosis which would favour $\mathrm{H}_{2}$ production. $\mathrm{N}$ - and P-deprivation that can also stimulate $\mathrm{H}_{2}$ production, but with lower $\mathrm{H}_{2}$ yields and longer induction time to reach an anoxic state ${ }^{4,5}$. Currently, green algae such as C. reinhardtii, Tetraspora sp. CU2551, and C. protothecoides have been preferred for $\mathrm{H}_{2}$ photoproduction $^{6-9}$. It is possible that other unknown green algal species may produce $\mathrm{H}_{2}$ better than the reported strains. In addition, since the induction of $\mathrm{H}_{2}$ photoproduction by $C$. reinhardtii was optimized under 
sulphur deprivation, deprivation of other nutrients could also induce the algae cells to produce $\mathrm{H}_{2}$.

In the current work, the $\mathrm{H}_{2}$-producing capacity of green microalgae was evaluated in response to different modified tris-acetate-phosphate medium ${ }^{10}$. We collected various fresh water samples in Thailand to isolate indigenous algal strains and screened for $\mathrm{H}_{2}$ production ability under S-deprivation, a combination of $\mathrm{N}$-limitation and S-deprivation, or a combination of N-limitation and P-starvation.

\section{MATERIALS AND METHODS}

\section{Microalgae samples collection}

Freshwater samples were collected from several ponds, canals, rivers, and reservoirs in Thailand. To collect microalgae samples, 201 of water samples were poured through a plankton net with $16 \mu \mathrm{m}$ pore size. The algal residue in the bucket of the plankton net was collected and then $1 \mathrm{ml}$ of the algal samples was added to the tris-acetate-phosphate (TAP) or Blue-Green (BG-11) medium.

\section{Isolation of pure cultures}

Several green algae were isolated using glass Pasteur pipettes and cultured in TAP or BG-11 liquid media with combinations of ampicillin, chloramphenicol, streptomycin, kanamycin, and carbendazim. The algal isolates were then cultivated at $25 \pm 1{ }^{\circ} \mathrm{C}$ under $20 \mu \mathrm{mol}$ photons $\mathrm{m}^{-2} \mathrm{~s}^{-1}$ of illumination for 7-30 days. The streak plate method was then used to separate the microalgae, bacteria, and fungi on TAP agar medium. The above process was repeated several times until there was no fungal or bacterial contamination. Then, each pure, individual colony was picked and cultured on separate TAP agar plates for further study. The morphology of the collected algae was observed and photographed using a light microscope (BX 51, Olympus Imaging Corp., Japan). Morphological characteristics were identified according to John ${ }^{11}$.

\section{Culture conditions}

Algae cells were cultured in standard TAP medium containing $7 \mathrm{mM} \mathrm{NH}_{4} \mathrm{Cl}$ at $\mathrm{pH} 7.3 \pm 0.1$ and kept at $25 \pm 1{ }^{\circ} \mathrm{C}$ under a light/dark regime of $14: 10 \mathrm{~h}$ for 4-7 days. Cool white fluorescent lamps of about $35 \mu \mathrm{mol}$ photons $\mathrm{m}^{-2} \mathrm{~s}^{-1}$ were used for illumination.

\section{DNA extraction}

DNA from algal cells was extracted using a DNAeasy Plant mini-kit (Qiagen, Germany) according to the manufacturer's instructions. The presence or absence of the extracted DNA was determined by electrophoresis in $1 \%$ agarose gel and stained with ethidium bromide. The DNA concentration was quantified using a UV-spectrophotometer (8453, Agilent Technologies, Inc., Germany) at an optical density of $260 \mathrm{~nm}$.

\section{Polymerase Chain reaction (PCR) amplification of 18S rDNA gene and ITS regions}

The 18S rDNA sequences were amplified using the universal eukaryotic primers, 5'-GTCAGAGGTGAA ATTCTTGGATTTA- $3^{\prime}$ as forward and $5^{\prime}$-AGGGCA GGGACGTAATCAACG $-3^{\prime}$ as reverse primer. The expected amplified product size of the 18S rDNA gene was about $750 \mathrm{bp}$. The ITS regions (ITS1, 5.8S, and ITS2) of ribosome were amplified using the following primers: forward, 5'-GAAGTCGTAACAA GGTTTCC $-3^{\prime}$ and reverse, $5^{\prime}$-TCCTGGTTAGTTTCT TTTCC $-3^{\prime 12}$. PCR amplification was carried out in a Px2 Thermal Cycler (Thermo Electron Corporation, USA). For amplifying the 18S rDNA gene, DNA was denatured at $95^{\circ} \mathrm{C}$ for $4 \mathrm{~min}$ and followed by 30 cycles of denaturing at $95^{\circ} \mathrm{C}$ for $30 \mathrm{~s}$, annealing at $60^{\circ} \mathrm{C}$ for $30 \mathrm{~s}$, extension at $72^{\circ} \mathrm{C}$ for $30 \mathrm{~s}$, and a final elongation step at $72{ }^{\circ} \mathrm{C}$ for $10 \mathrm{~min}$, then holding at $4^{\circ} \mathrm{C}$. For the amplification of ITS regions, a touchdown amplification program was used. DNA was denatured at $95^{\circ} \mathrm{C}$ for 4 min and followed by 30 cycles of denaturation at $95^{\circ} \mathrm{C}$ for $30 \mathrm{~s}$, annealing at $60^{\circ} \mathrm{C}$ (dropping $0.5^{\circ} \mathrm{C}$ each cycle) for $30 \mathrm{~s}$, and extension at $72^{\circ} \mathrm{C}$ for $40 \mathrm{~s}$. Amplification of ITS regions was continued using a second 30 cycles of denaturation at $95^{\circ} \mathrm{C}$ for $30 \mathrm{~s}$, annealing at $45^{\circ} \mathrm{C}$ for $30 \mathrm{~s}$, extension at $72{ }^{\circ} \mathrm{C}$ for $40 \mathrm{~s}$, and a final elongation step at $72{ }^{\circ} \mathrm{C}$ for $7 \mathrm{~min}$, then holding at $4^{\circ} \mathrm{C}$. All PCR amplifications were performed in $25 \mu \mathrm{l}$ master mix solution containing $25 \mu \mathrm{l}$ of total DNA, 1X Taq buffer, $1.0 \mu \mathrm{M}$ of dNTPs, $1.5 \mathrm{mM} \mathrm{MgCl}_{2}$, $0.4 \mu \mathrm{M}$ of each primer, and 1.0 unit of Taq DNA polymerase. The PCR products were determined using electrophoresis in 1\% (W/V) agarose gel in $1 \times$ TBE buffer and visualized using ethidium bromide straining.

\section{Sequencing and phylogenetic analysis}

The PCR products were cleaned up using the QIAquick Gel Extraction kit (Qiagen, Germany). For sequencing, $30 \mathrm{ng}$ of PCR product was used as a template with $10 \mathrm{pmol} / \mu \mathrm{l}$ of the above primers and made to a final volume of $10 \mu \mathrm{l}$ with distilled water. The samples were sent to the 1 st base company (Malaysia) for sequencing. The sequence similarity 
was compared with a data set of algal sequences in the NCBI database. A neighbour joining (NJ) tree was obtained using the software MEGA $5^{13}$. The credibility of the branching orders were analysed by bootstrap analysis of 1000 replicates.

\section{Effect of nutrient deprivation on population growth and chlorophyll content}

To determine the effects of nutrient deprivation, algal cultures were harvested by centrifugation $\left(2500 \mathrm{~g}, 5 \mathrm{~min}, 25^{\circ} \mathrm{C}\right.$ ) and washed twice with different TAP media (TAP, S-deprivation (TAP-S), N-deprivation (TAP-N), and P-deprivation (TAP-P)). Then the pellets were resuspended in each TAP medium to an initial optical density of $2.0 \times 10^{6}$ cells $/ \mathrm{ml}$. The biomass production was determined by the chlorophyll content and cell density values. For cell density, cells were counted using a haemocytometer under a light microscope (CH 30, Olympus Imaging Corp., Japan).

\section{Screening for $\mathrm{H}_{2}$ production}

To determine the $\mathrm{H}_{2}$-producing ability, the microalgae were pre-cultured in TAP medium at $25 \pm 1{ }^{\circ} \mathrm{C}$ under $35 \mu \mathrm{mol}$ photons $\mathrm{m}^{-2} \mathrm{~s}^{-1}$ of illumination using a light/dark regime of $14: 10 \mathrm{~h}$ for 4-7 days. Three different TAP media were used to screen for the $\mathrm{H}_{2}$-producing ability of microalgae. For the first culture medium (TAP-S medium), all isolates of the green algae were pre-cultured in TAP medium containing $7 \mathrm{mM} \mathrm{NH}_{4} \mathrm{Cl}$ and the algal cultures were harvested at the late logarithmic phase using centrifugation $\left(2500 \mathrm{~g}, 5 \mathrm{~min}, 25^{\circ} \mathrm{C}\right)$ and washed twice with TAP-S medium. The S-deprivation medium was obtained by replacing all sulphate salts with chloride salts. Then the pellets were resuspended in TAP-S medium. An optical density of $2.5-3.5 \times 10^{7}$ cells $/ \mathrm{ml}$ was used for all treatments. All cell cultures were transferred into $20 \mathrm{ml}$ glass vials, sealed with butyl rubber stoppers and bubbled with argon gas for $5 \mathrm{~min}$ to remove $\mathrm{O}_{2}$ in the head space of the vial. The sealed glass vials were shaken at $110 \mathrm{rpm}$ and exposed to a continuous light intensity of $35 \mu \mathrm{mol}$ photons $\mathrm{m}^{-2} \mathrm{~s}^{-1}$. High $\mathrm{H}_{2}$ producing strains cultured in the $20 \mathrm{ml}$ glass vials were selected and transferred into $650 \mathrm{ml}$ bioreactors containing TAP-S medium under continuous light $(35 \mu \mathrm{mol}$ photons $\mathrm{m}^{-2} \mathrm{~s}^{-1}$ ). Each vessel was sealed with a butyl rubber stopper and fitted with an outlet tube connected to a graduated cylinder for gas collection by displacement of water ${ }^{3}$. For the second set of culture conditions (simultaneous N-limitation and S-deprivation), cells were grown in nitrogen-limited medium (TAP with $0.7 \mathrm{mM} \mathrm{NH}_{4} \mathrm{Cl}$ ) and then washed twice and cultured in simultaneous $\mathrm{N}$-limitation and S-deprivation (TAP-S with $0.7 \mathrm{mM} \mathrm{NH}_{4} \mathrm{Cl}$ ) medium.

For the third set of culture conditions (simultaneous N-limitation and P-starvation), cells were grown in nitrogen-limited medium (TAP containing $0.35 \mathrm{mM} \mathrm{NH}_{4} \mathrm{Cl}$ ) and then washed twice and cultured in simultaneous $\mathrm{N}$-limitation and P-deprivation (TAP-P with $0.35 \mathrm{mM} \mathrm{NH}_{4} \mathrm{Cl}$ ) medium. P-starvation medium was obtained by omitting phosphate.

\section{Measurement of $\mathrm{H}_{2}$ and $\mathrm{O}_{2}$ gas}

Hydrogen production was analysed using gas chromatography (GC) (GC-112A, Shanghai Phenic Optical Scientific Instrument Co. Ltd., China) equipped with a molecular sieve $5 \AA$ column using a Thermal Conductivity Detector. To separate $\mathrm{H}_{2}, \mathrm{O}_{2}$ and $\mathrm{N}_{2}$, argon was used as a carrier gas at a flow rate of $15 \mathrm{ml} / \mathrm{min}$. The packed column was maintained at $40^{\circ} \mathrm{C}$ and the temperature for the detector and injector was set at $100^{\circ} \mathrm{C}$. The total $\mathrm{H}_{2}$ and $\mathrm{O}_{2}$ volumes were calculated according to the peak area, which was pre-calibrated by injecting known concentrations of standard gases. The empirical equations for the $\mathrm{H}_{2}$ and $\mathrm{O}_{2}$ calculations were as follows: $\mathrm{H}_{2}(\mu \mathrm{l})=0.00001 \times$ Area $+0.5095 ; \mathrm{O}_{2}(\mu \mathrm{l})=$ $0.0007 \times$ Area +1.1045 . Area represents the value of the corresponding peak area of $\mathrm{H}_{2}$ and $\mathrm{O}_{2}$ detected using $\mathrm{GC}^{14}$.

\section{Measurement of chlorophyll content}

Chlorophyll in the cell cultures was extracted as described by Liu ${ }^{15}$ and total chlorophyll (mg/l) was calculated as $4.44 \times \mathrm{A}_{666 \mathrm{~nm}}+19.71 \times \mathrm{A}_{653 \mathrm{~nm}}$, where $A_{666 \mathrm{~nm}}$ and $A_{653 \mathrm{~nm}}$ correspond to the absorbance of supernatant at $666 \mathrm{~nm}$ and $653 \mathrm{~nm}$ wavelength, respectively, with a $1 \mathrm{~cm}$ path of the cuvette.

\section{RESULTS AND DISCUSSION}

\section{Collection of samples, isolation, and purification of microalgal strains}

Among the collected samples, at least 86 isolates of axenic uniclonal cultures were obtained through a streak plate method. Among these, 43 isolates were successfully cultivated in TAP medium to densities of over $2.0 \times 10^{6}$ cells $/ \mathrm{ml}$. These 43 isolates were taken for screening of their $\mathrm{H}_{2}$-producing ability.

\section{Strain identification}

The selected 43 isolates were morphologically identified as belonging to the following genera: Chlamy- 

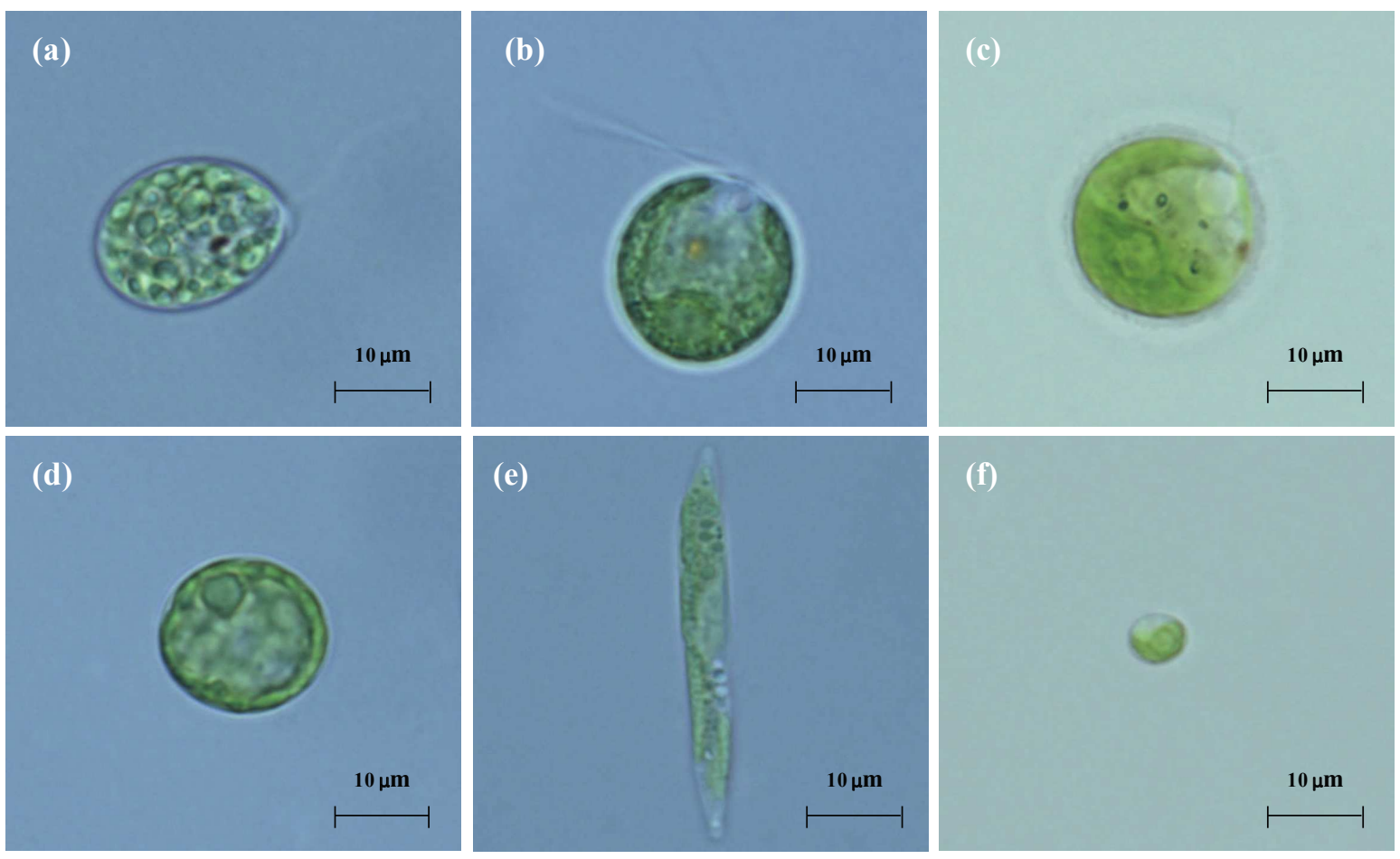

Fig. 1 Observation using light microscopy of different green algal species isolated from freshwater samples. (a) Chlamydomonas sp. KU103, (b) Chlamydomonas sp. KU106, (c) Chlamydomonas sp. KU108, (d) Coelastrella sp. KU501, (e) Monoraphidium sp. KU401, (f) C. sorokiniana KU204.

domonas (10 isolates), Chlorella (15 isolates), Micractinium (2 isolates), Scenedesmus, (8 isolates), Coelastrella (7 isolates), and Monoraphidium (1 isolate). The morphology of some isolated green microalgal species observed under the light microscope is shown in Fig. 1. To confirm the genus of the algae samples, $18 \mathrm{~S}$ rDNA gene partial sequences were subjected to a BLAST search. Analysis of the $18 \mathrm{~S}$ rDNA gene showed that the sequence similarity of the isolated strains was closely related to Chlamydomonas sp. (98-99\%), Chlorella sp. (99-100\%), Coelastrella sp. (98-99\%), Micractinium sp. (99100\%), Monoraphidium sp. (99\%), and Scenedesmus (99-100\%) (data not shown). This BLAST result from 18S rDNA correlated with the grouping from morphological characteristics.

To identify the isolates to the species level, the ITS sequences were used in alignments (CLUSTAL-X) prior to Bootstrap NJ phylogenetic tree determination (Fig. 2). The ITS sequences were aligned and compared with a data set consisting of 16 sequences retrieved from NCBI databases. From the phylogenetic analysis of the ITS sequences, the microalgae samples could be categorized into four different clades, i.e., Chlorella, Chlamydomonas,
Coelastrella, and Micractinium clades (Fig. 2). In the Chlorella clade, the isolates KU202, KU203, KU204, KU205, KU206, and KU208 formed a cluster with C. sorokiniana with $76 \%$ bootstrap support and showed 99\% sequence similarity to C. sorokiniana JQ898145.1. Three Chlorella isolates (KU207, KU209, and KU211) were closely related to C. sorokiniana UTEX 1665 KJ676113.1, Chlorella sp. Iso4 JX041600.1 and C. sorokiniana UTEX 2805 KJ676109.1, respectively, (98\% similarity). Moreover, the isolates KU201, KU213, KU215, KU217, and KU220 were clustered with C. lewinii CCAP 211/90 FM205861.1 (99\% similarity). In the Micractinium clade, the isolates KU210 and KU212 were clustered with Micractinium sp. CCAP 248/7 (96\% similarity), and Micractinium sp. JX889639.1 (93\% similarity), respectively. In the Chlamydomonas clade, two Chlamydomonas sp. isolates (KU105 and KU106) were clustered with C. debaryana FR865600.1 (94\% similarity). Chlamydomonas sp. isolates (KU111) were closely related to C. reinhardtii CC-620 JX839533.1. Moreover, Chlamydomonas sp. isolates (KU101, KU102, KU103, KU104, KU107, and KU108) were clustered with Chlamydomonas sp. but exhibited 


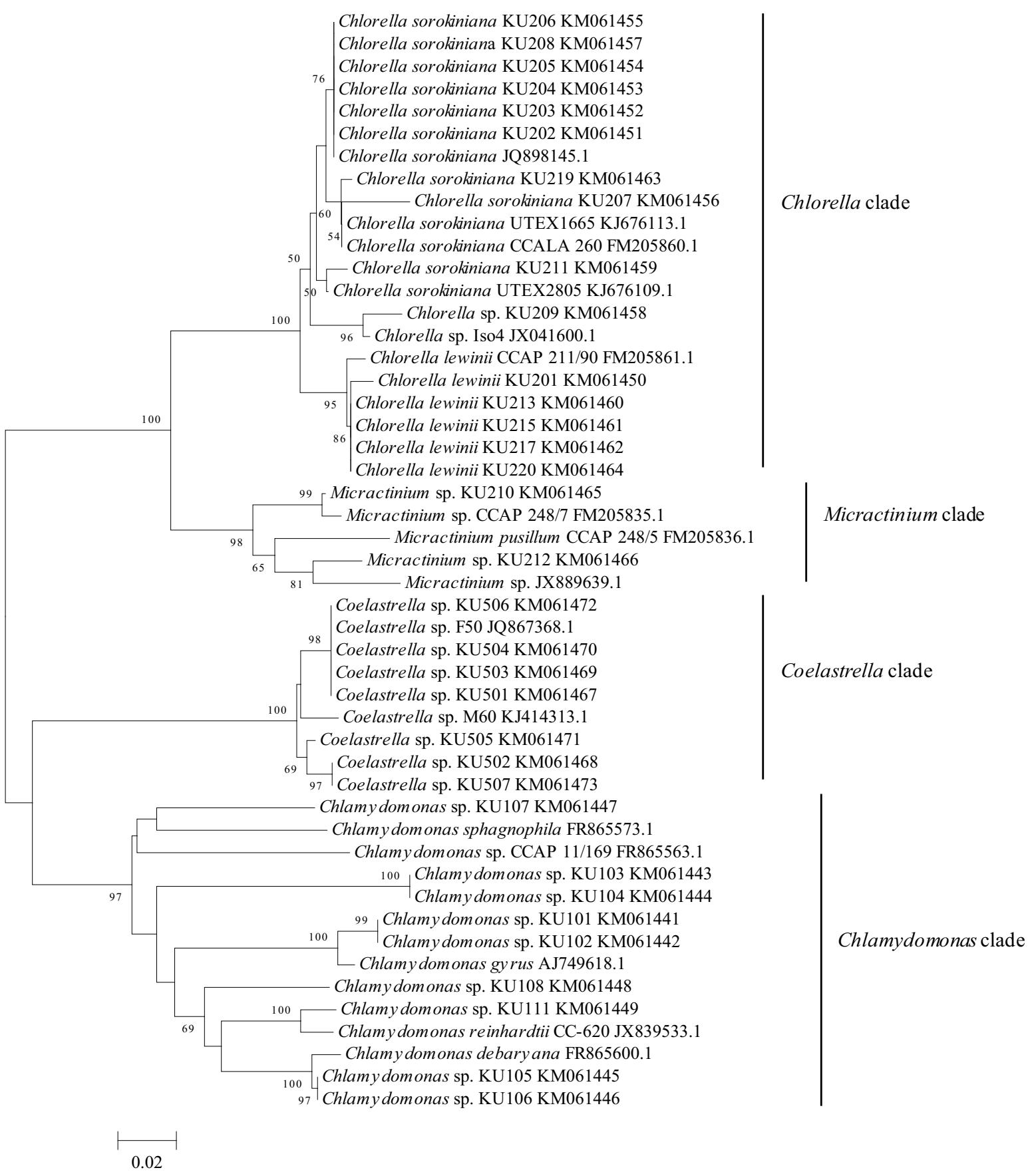

Fig. 2 Phylogenetic tree of green microalgae constructed from ITS sequences (ITS1, 5.8S, and ITS2).

low similarity (85-90\%). In the Coelastrella clade, four Coelastrella isolates-namely, KU501, KU503, KU504, and KU506 formed a cluster with Coelastrella sp. with strong bootstrap support (98\%) and exhibited 99-100\% sequence similarity to Coelastrella sp. F50 JQ867368.1. The ITS phylogenetic tree suggested a high homology among most strains to the reference strains. ITS sequences could therefore be used to identify the genus or species of these algae strains. The result agrees with Qiao ${ }^{16}$, where the difference between genomic base composition and rDNA similarity in different strains of algae was reported. 

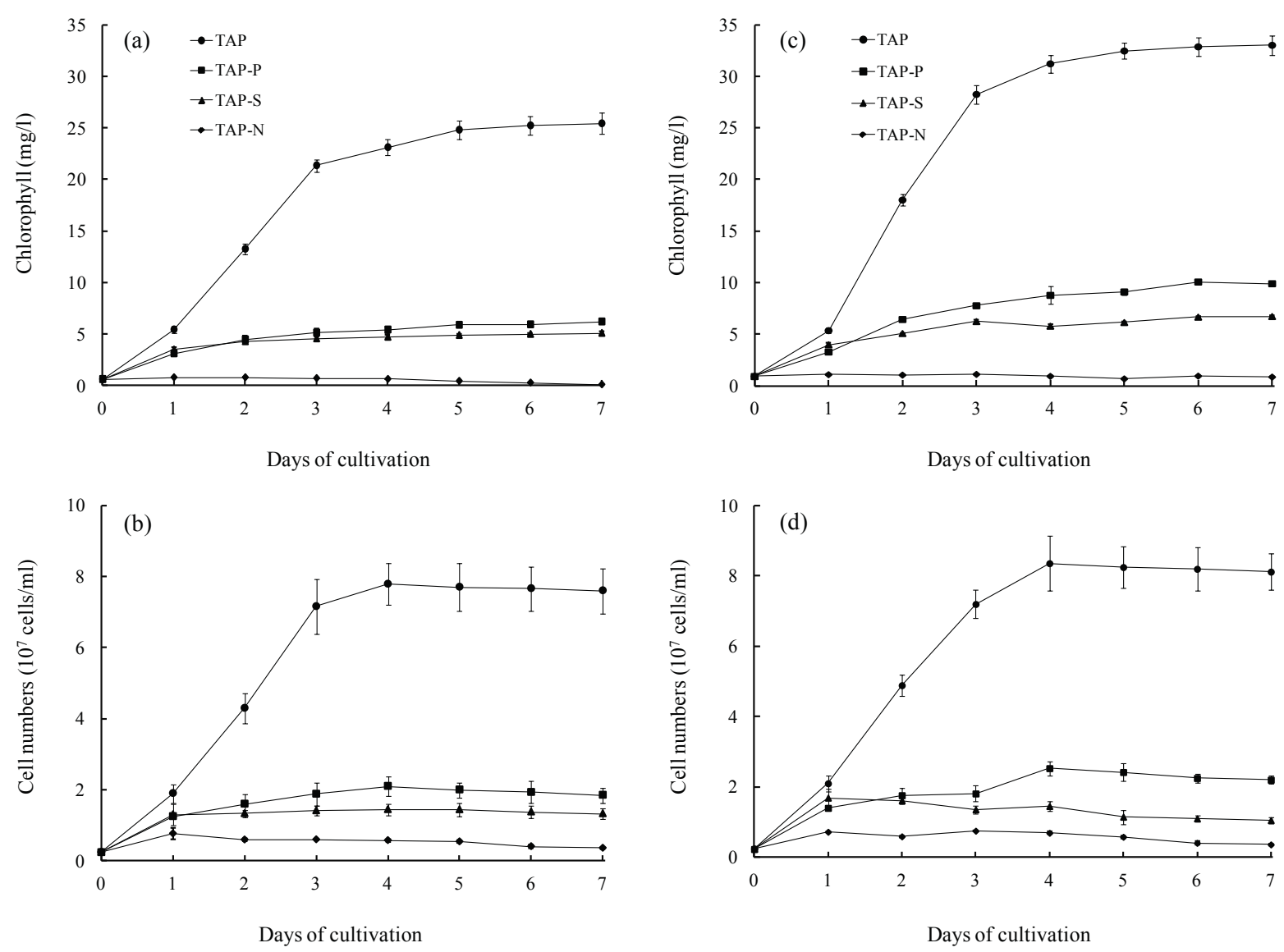

Fig. 3 Changes in chlorophyll content and cell numbers in C. sorokiniana KU207 and Chlorella sp. KU209 exposed to various TAP media: (a) chlorophyll content and (b) cell numbers in C. sorokiniana KU207, (c) chlorophyll content and (d) cell numbers in Chlorella sp. KU209.

\section{Effect of nutrient deprivation on chlorophyll content and cell numbers in C. sorokiniana KU207 and Chlorella sp. KU209}

After growing the Chlorella sp. in N-, S-, and P-deprivation, the total chlorophyll content and cell numbers were dramatically reduced. The chlorophyll content and cell numbers in N-starved cells showed the greatest decrease, followed by S-deprived, then P-deprived cells compared to those of cells grown in normal TAP medium (Fig. 3). The chlorophyll content in C. sorokiniana KU207 and Chlorella sp. KU209 declined by approximately $85 \%$ and $80 \%$, respectively, after 1 day of growth under the N-deprivation. In P or S-starved cells however, the chlorophyll content of C. sorokiniana KU207 and Chlorella sp. KU209 decreased by approximately 65\%-70\% after 2 days. The reduction in the chlorophyll content correlated with the decline in cell numbers. These results indicated that nutrient limitation led to a loss of chlorophyll content and cell numbers in these algae.

Essential macronutrients such as sulphur, nitrogen, or phosphorus have an effect on the growth of phototrophic microalgae ${ }^{17}$. A lack of these nutrients results in the arrest of cell division and the cessation of cell growth ${ }^{18}$. Nitrogen deprivation is a severe stress condition for all organisms because nitrogen is a major component of proteins and nucleic acid. A limitation of nitrogen in Chlamydomonas cells resulted in lower cellular chlorophyll contents and LHCII levels ${ }^{19}$. The differences in pigmentation and antennae composition probably have an impact on light energy transfer to the photosystems ${ }^{5}$. Sulphur deprivation causes reversible inhibition of photosynthetic activity in algae. In the absence of $\mathrm{S}$, PSII-dependent $\mathrm{O}_{2}$-evolving activity in algal cells was gradually inhibited due to their inability to resynthesize the D1 protein ${ }^{20}$. As with S-deprivation, P-deprivation can also inhibit $\mathrm{O}_{2}$ evolution activity 
in algae. The inhibition process of $\mathrm{O}_{2}$-evolving activity in algal cells by S-deprivation is however faster than by P-deprivation ${ }^{20}$. Moreover, P-deprivation in the medium also leads to the reduction of the $\mathrm{CO}_{2}$ fixation rate due to the depletion of phosphorylated intermediates in the pentose phosphate cycle ${ }^{21,22}$.

In addition to the study of S-deprivation, the results indicated that $\mathrm{P}$ - and $\mathrm{N}$-deprivation also have an effect on the growth and photosynthetic activity of the phototrophic microalgae. Moreover, under these stress conditions, $\mathrm{O}_{2}$ evolution was inhibited and $\mathrm{H}_{2}$ gas was generated. The ability of green microalgae to produce $\mathrm{H}_{2}$ under various nutrient deprivations are reported in the subsequent results (see below).

\section{Screening for $\mathrm{H}_{2}$ photoproduction of freshwater green algae}

The $\mathrm{H}_{2}$-producing ability of the 43 green algal isolates was tested under S-deprivation (TAP-S containing $7 \mathrm{mM} \mathrm{NH}_{4} \mathrm{Cl}$ ), a combination of N-limitation and S-deprivation (TAP-S with $0.7 \mathrm{mM} \mathrm{NH}_{4} \mathrm{Cl}$ ), and a combination of N-limitation and P-starvation (TAP-P with $0.35 \mathrm{mM} \mathrm{NH}_{4} \mathrm{Cl}$ ) (Table 1). Most isolated green algal strains had the ability to generate $\mathrm{H}_{2}$ under S-deprivation, consisting of Chlamydomonas, Chlorella, Micractinium, Scenedesmus, Monoraphidium, and Coelastrella. We report here, for the first time, that C. lewinii, Micractinium sp., Coelastrella sp., and Monoraphidium sp. can also produce $\mathrm{H}_{2}$ gas. In addition, most tested strains of Chlorella and all the strains of Chlamydomonas had enhanced $\mathrm{H}_{2}$ production when cultured on simultaneous N-limitation and S-deprivation (Table 1). This fascinating result however was not found in any strain of Coelastrella, Micractinium, or Scenedesmus. Under $\mathrm{S}$-deprivation, microalgae are capable of $\mathrm{H}_{2}$ photoproduction $^{3}$. The lack of sulphur causes a gradual inhibition of PSII-dependent $\mathrm{O}_{2}$-evolving activity in algal cells. When the bioreactors were sealed, the oxygen in the headspace of the bioreactors was gradually consumed by microalgae because of cellular respiration and the bioreactor became anaerobic. Algal strains evolved different amounts of $\mathrm{H}_{2}$, depending upon various factors such as the ability of each strain, nutrient composition, light intensity, temperature, $\mathrm{pH}$, and oxygen when incubated under nutrient deprivation conditions in the light. The hydrogenase enzyme that catalyses an $\mathrm{H}_{2}$ production reaction in algae is sensitive oxygen. Under aerobic conditions, however, some species could produce $\mathrm{H}_{2}$ (Table 1). These species probably are tolerant to oxygen or the activity of hydrogenase may not be totally inhibited ${ }^{14}$.

All 15 isolates of Chlorella sp. could produce $\mathrm{H}_{2}$ under TAP-S, TAP-S with $0.7 \mathrm{mM} \mathrm{NH}_{4} \mathrm{Cl}$ and TAP-P containing $0.35 \mathrm{mM} \mathrm{NH}_{4} \mathrm{Cl}$ (Table 1). Five C. sorokiniana isolates (KU204, KU205, KU206, KU207, and KU208) continuously produced $\mathrm{H}_{2}$ after transferring from standard TAP medium to stress conditions. These strains needed however an induction time of at least $24 \mathrm{~h}$ to reach an anoxic state under TAP-S. On the other hand, in TAP-S with $0.7 \mathrm{mM} \mathrm{NH}_{4} \mathrm{Cl}$ and TAP-P containing $0.35 \mathrm{mM}$ $\mathrm{NH}_{4} \mathrm{Cl}$, the anaerobic state was reached $3 \mathrm{~h}$ earlier, resulting in higher $\mathrm{H}_{2}$ accumulation. Among these isolates, C. sorokiniana KU204 showed the highest $\mathrm{H}_{2}$ production ability, with the total $\mathrm{H}_{2}$ yield under TAP-S, TAP-P containing $0.35 \mathrm{mM} \mathrm{NH}_{4} \mathrm{Cl}$ and TAP-S with $0.7 \mathrm{mM} \mathrm{NH}_{4} \mathrm{Cl}$ being about 46.2 , 69.0, and $89.6 \mathrm{ml} / 1$, respectively (Fig. 4). Interestingly, besides S-deprivation, the lack of phosphorus under N-limitation can also limit $\mathrm{O}_{2}$ evolution in the algae cells. Five C. lewinii isolates (KU201, KU213, KU215, KU217, and KU220) generated small amounts of $\mathrm{H}_{2}$ because of the presence of oxygen in the medium or the bioreactor headspace. This oxygen inhibits $\mathrm{H}_{2}$ production. The highest content of $\mathrm{H}_{2}$ in C. lewinii (KU213, KU215, KU217, and KU220) was found under TAP-S followed by TAP-S with $0.7 \mathrm{mM} \mathrm{NH}_{4} \mathrm{Cl}$ and TAP-P containing $0.35 \mathrm{mM} \mathrm{NH}_{4} \mathrm{Cl}$. Under these nutrient deprivation conditions, however, the strains generated large amounts of oxygen which inactivated hydrogenase and inhibited $\mathrm{H}_{2}$ production. On the contrary, the C. lewinii strain KU201 produced $\mathrm{H}_{2}$ yields under TAP-S with $0.7 \mathrm{mM} \mathrm{NH}_{4} \mathrm{Cl}$ and under TAP-P containing $0.35 \mathrm{mM} \mathrm{NH}_{4} \mathrm{Cl}$ which were more than under TAP-S. Under TAP-S with $0.7 \mathrm{mM} \mathrm{NH}_{4} \mathrm{Cl}$, the C. lewinii strain KU201 evolved less oxygen, while under TAP-P containing $0.35 \mathrm{mM} \mathrm{NH}_{4} \mathrm{Cl}$, the C. lewinii strain KU201 did not evolve oxygen after 12 h. Chlorella sp. KU209 and C. sorokiniana KU211 were also capable of producing $\mathrm{H}_{2}$ under TAP-S, TAP-S with $0.7 \mathrm{mM} \mathrm{NH}_{4} \mathrm{Cl}$ and TAP-P containing $0.35 \mathrm{mM} \mathrm{NH}_{4} \mathrm{Cl}$. The $\mathrm{H}_{2}$ yield by Chlorella sp. KU209 was however the same in all medium conditions. Chlorella sorokiniana KU211 produced more $\mathrm{H}_{2}$ under TAP-S with $0.7 \mathrm{mM} \mathrm{NH}_{4} \mathrm{Cl}$ than TAP-P containing $0.35 \mathrm{mM} \mathrm{NH}_{4} \mathrm{Cl}$ because the cultures under TAP-P containing $0.35 \mathrm{mM} \mathrm{NH}_{4} \mathrm{Cl}$ could generate both $\mathrm{H}_{2}$ and $\mathrm{O}_{2}$. Besides S-deprivation, Chlorella sp. can generate $\mathrm{H}_{2}$ gas under TAP-P containing $0.35 \mathrm{mM} \mathrm{NH}_{4} \mathrm{Cl}$ because the starvation of phosphorus can also inhibit $\mathrm{O}_{2}$-evolving activity. P-deprivation in algae is known to result in an anaer- 
Table $1 \mathrm{H}_{2}$ production by 43 freshwater green algae.

\begin{tabular}{|c|c|c|c|c|c|c|c|}
\hline \multirow[t]{3}{*}{ Green algae } & \multirow[t]{3}{*}{ Strain } & \multicolumn{6}{|c|}{ Treatment } \\
\hline & & \multicolumn{2}{|l|}{ TAP-S } & \multicolumn{2}{|c|}{ TAP-S (0.7 mM NH4Cl) } & \multicolumn{2}{|c|}{ TAP-P (0.35 mM NH4Cl) } \\
\hline & & $\mathrm{H}_{2}$ yield $(\mathrm{ml} / \mathrm{l})$ & Time $^{\dagger}$ & $\mathrm{H}_{2}$ yield $(\mathrm{ml} / \mathrm{l})$ & Time $^{\dagger}$ & $\mathrm{H}_{2}$ yield $(\mathrm{ml} / \mathrm{l})$ & Time $^{\dagger}$ \\
\hline C. sorokiniana & KU202 & 8.87 & - & 13.02 & - & 8.15 & $<12 \mathrm{~h}^{*}$ \\
\hline C. sorokiniana & KU203 & 9.07 & - & 13.86 & - & 8.39 & $<12 \mathrm{~h}^{*}$ \\
\hline C. sorokiniana & KU204 & 46.20 & $<24 \mathrm{~h}^{*}$ & 89.64 & $<3 \mathrm{~h}^{*}$ & 69.00 & $<3 h^{*}$ \\
\hline C. sorokiniana & KU205 & 15.99 & $<24 \mathrm{~h}^{*}$ & 27.98 & $<3 \mathrm{~h}^{*}$ & 20.95 & $<3 h^{*}$ \\
\hline C. sorokiniana & KU206 & 10.77 & $<24 \mathrm{~h}^{+}$ & 29.16 & $<3 \mathrm{~h}^{\ddagger}$ & 20.13 & $<3 \mathrm{~h}^{+}$ \\
\hline C. sorokiniana & KU207 & 12.49 & $<24 \mathrm{~h}^{*}$ & 24.35 & $<3 \mathrm{~h}^{*}$ & 14.80 & $<3 \mathrm{~h}^{*}$ \\
\hline C. sorokiniana & KU208 & 16.78 & $<24 \mathrm{~h}^{+}$ & 30.18 & $<3 \mathrm{~h}^{+}$ & 17.51 & $<3 h^{*}$ \\
\hline C. sorokiniana & KU219 & 5.53 & - & 18.28 & $<12 \mathrm{~h}^{*}$ & 11.15 & $<12 \mathrm{~h}^{+}$ \\
\hline C. sorokiniana & KU211 & 6.74 & - & 14.01 & $<12 \mathrm{~h}^{*}$ & 2.74 & - \\
\hline C. lewinii & KU201 & 5.10 & - & 13.03 & - & 11.50 & $<12 \mathrm{~h}^{*}$ \\
\hline C. lewinii & KU213 & 5.87 & - & 5.63 & - & 2.93 & - \\
\hline C. lewinii & KU215 & 6.97 & - & 6.93 & - & 2.87 & - \\
\hline C. lewinii & KU217 & 6.59 & - & 5.07 & - & 2.91 & - \\
\hline C. lewinii & KU220 & 8.20 & - & 6.36 & - & 2.71 & - \\
\hline Chlorella sp. & KU209 & 11.96 & - & 12.67 & - & 10.27 & $<12 \mathrm{~h}^{*}$ \\
\hline Micractinium sp. & KU210 & 3.17 & - & 0.51 & - & 0.32 & - \\
\hline Micractinium sp. & KU212 & 0.90 & - & 0.35 & - & 0.32 & - \\
\hline Coelastrella sp. & KU501 & 0.32 & - & 0.25 & - & 0.31 & - \\
\hline Coelastrella sp. & KU502 & 0.47 & - & 1.13 & - & 0.41 & - \\
\hline Coelastrella sp. & KU503 & 0.38 & - & 0.32 & - & 0.27 & - \\
\hline Coelastrella sp. & KU504 & 0.43 & - & 0.36 & - & 0.33 & - \\
\hline Coelastrella sp. & KU505 & 1.95 & - & 1.39 & - & 0.72 & - \\
\hline Coelastrella sp. & KU506 & 0.36 & - & 0.31 & - & 0.26 & - \\
\hline Coelastrella sp. & KU507 & 0.40 & - & 1.08 & - & 0.38 & - \\
\hline Chlamydomonas sp. & KU101 & 1.67 & - & 2.97 & - & & \\
\hline Chlamydomonas sp. & KU102 & 1.40 & - & 2.54 & - & & \\
\hline Chlamydomonas sp. & KU103 & 1.78 & - & 2.89 & - & & \\
\hline Chlamydomonas sp. & KU104 & 1.37 & - & 2.63 & - & & \\
\hline Chlamydomonas sp. & KU105 & 7.69 & $<36 \mathrm{~h}^{*}$ & 16.90 & $<36 \mathrm{~h}^{*}$ & & \\
\hline Chlamydomonas sp. & KU106 & 24.4 & $<36 \mathrm{~h}^{*}$ & 62.00 & $<36 \mathrm{~h}^{*}$ & & \\
\hline Chlamydomonas sp. & KU107 & $0^{*}$ & - & 0.30 & - & & \\
\hline Chlamydomonas sp. & KU108 & 0.42 & - & 1.66 & - & & \\
\hline Chlamydomonas sp. & KU109 & 0.58 & - & 2.17 & - & & \\
\hline Chlamydomonas sp. & KU111 & 11.6 & $<36 \mathrm{~h}^{*}$ & 30.60 & $<36 \mathrm{~h}^{*}$ & & \\
\hline Scenedesmus sp. & KU301 & 2.82 & - & 0.34 & - & & \\
\hline Scenedesmus sp. & KU302 & 4.20 & - & 0.37 & - & & \\
\hline Scenedesmus sp. & KU303 & 0.35 & - & 0* & - & & \\
\hline Scenedesmus sp. & KU304 & 0.39 & - & $0^{*}$ & - & & \\
\hline Scenedesmus sp. & KU305 & 0.42 & - & $0^{*}$ & - & & \\
\hline Scenedesmus sp. & KU306 & 0.34 & - & 0* & - & & \\
\hline Scenedesmus sp. & KU308 & 2.56 & - & 0.32 & - & & \\
\hline Scenedesmus sp. & KU309 & 0.39 & - & $0^{*}$ & - & & \\
\hline Monoraphidium sp. & KU401 & 1.32 & - & 2.04 & - & & \\
\hline
\end{tabular}

$\dagger$ Time to reach an anoxic state.

$* \mathrm{O}_{2}$ not detected.

" $\mathrm{H}_{2}$ not detected. 


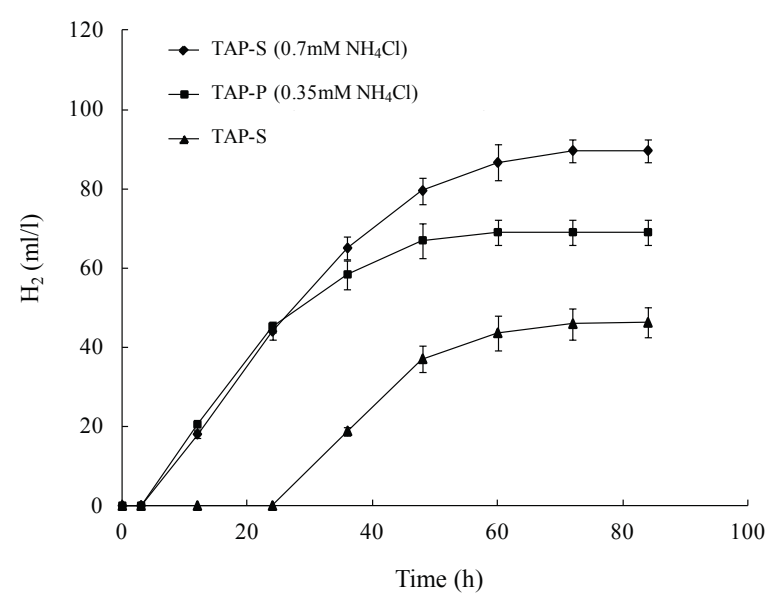

Fig. $4 \mathrm{H}_{2}$ photoproduction by C. sorokiniana KU204 under TAP-S, TAP-S with $0.7 \mathrm{mM} \mathrm{NH}_{4} \mathrm{Cl}$ and TAP-P containing $0.35 \mathrm{mM} \mathrm{NH}_{4} \mathrm{Cl}$.

obic state ${ }^{20}$, and in higher plants, where P-deprivation leads to a decrease in the light-saturated rate of photosynthesis ${ }^{21-24}$. Moreover, sustained $\mathrm{H}_{2}$ photoproduction in C. reinhardtii cultures can be accomplished by inoculating the washed algae into P-deprived medium at low initial cell densities (below $2 \mathrm{mg} \mathrm{Chl/l)}{ }^{4}$. The algal cultures under TAP-P containing $0.35 \mathrm{mM} \mathrm{NH}_{4} \mathrm{Cl}$ can be further improved by optimizing the cultivation conditions to enhance the $\mathrm{H}_{2}$ yield. Achieving sulphur deprivation in marine strains is however difficult because of the high concentration of sulphates in seawater.

Chlamydomonas strains (KU105, KU106, and KU111) were able to produce $\mathrm{H}_{2}$ in the first $36 \mathrm{~h}$ under continuous illumination in TAP-S and TAP-S with $0.7 \mathrm{mM} \mathrm{NH}_{4} \mathrm{Cl}$. On the other hand, Chlamydomonas strains (KU101, KU102, KU103, KU104, KU107, KU108, and KU109) were also able to generate $\mathrm{H}_{2}$ gas but could not shorten the time to reach an anoxic state, resulting in less $\mathrm{H}_{2}$ accumulation than for the first three Chlamydomonas strains. Among the Chlamydomonas strains, the highest $\mathrm{H}_{2}$ production was Chlamydomonas sp. KU106, and the maximum $\mathrm{H}_{2}$ gas production under TAP-S and TAP-S with $0.7 \mathrm{mM} \mathrm{NH}_{4} \mathrm{Cl}$ was about 24.4 and $62.0 \mathrm{ml} / 1$, respectively (Fig. 5).

Two Micractinium sp. strains (KU210 and KU212) produced $\mathrm{H}_{2}$ under the test conditions but with low $\mathrm{H}_{2}$ yield. Moreover, the $\mathrm{H}_{2}$ production under TAP-S with $0.7 \mathrm{mM} \mathrm{NH}_{4} \mathrm{Cl}$ and TAP-P containing $0.35 \mathrm{mM} \mathrm{NH}_{4} \mathrm{Cl}$ was less than that for the TAP-S medium because of the nitrogen limitation in the medium and oxygen production by algae.

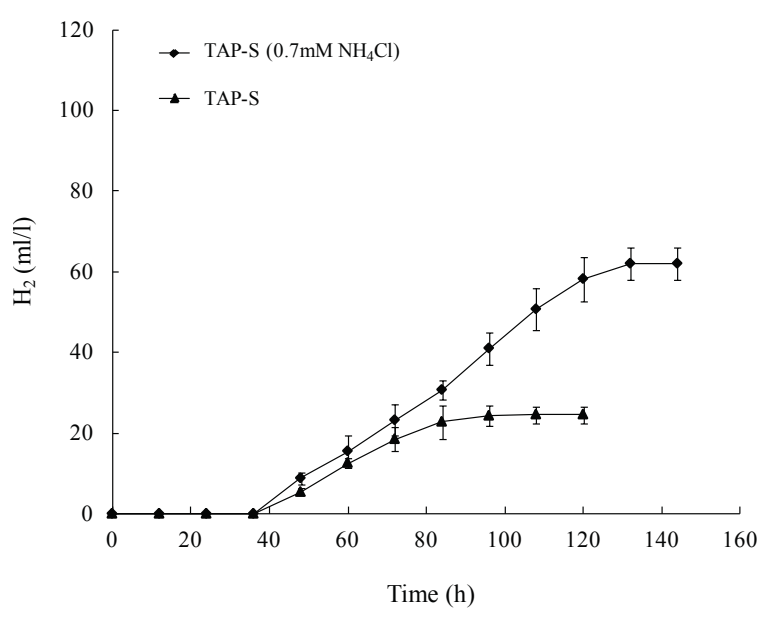

Fig. $5 \mathrm{H}_{2}$ photoproduction by Chlamydomonas sp. KU106 under TAP-S and TAP-S with $0.7 \mathrm{mM} \mathrm{NH}_{4} \mathrm{Cl}$.

Coelastrella sp. (all strains) and Scenedesmus sp. strains (KU303, KU304, KU305, KU306, and KU309) generated small amounts of $\mathrm{H}_{2}$ and rapidly lost vitality after transferring them to the tested media. The cultures turned from a green to a yellow colour and the algae died just a few days after transfer. It appears that microelement starvation involving sulphur, phosphorous, and nitrogen plays an important role in the cell metabolism of these algae. Monoraphidium sp. KU401 evolved less $\mathrm{H}_{2}$ under TAP-S with $0.7 \mathrm{mM} \mathrm{NH}_{4} \mathrm{Cl}$ and TAP-P containing $0.35 \mathrm{mM} \mathrm{NH}_{4} \mathrm{Cl}$ and generated $\mathrm{O}_{2}$ at the same time. Our results demonstrate that different species of microalgae could produce $\mathrm{H}_{2}$ at various levels. $\mathrm{H}_{2}$ production ability had been found to depend on the strain, nutrient composition, $\mathrm{pH}$, oxygen, light intensity, temperature, optical density and agitation $^{14,25}$. In addition, this ability to produce $\mathrm{H}_{2}$ may be related to specific anaerobic/low light habitats where the algae require the photobiological $\mathrm{H}_{2}$ production capacity to survive ${ }^{12}$.

Most tested Chlorella, but not Chlamydomonas, strains reached an anoxic state faster in a medium with simultaneous $\mathrm{N}$-limitation and S-deprivation than in a medium with S-deprivation. In addition, when those strains of Chlorella grown in medium with simultaneous N-limitation and S-deprivation exhibited an increased $\mathrm{H}_{2}$ production. Some could not induce an anoxic state throughout the experiment. However, such regularity was not found in Chlamydomonas (Table 1). Thus the mechanism of $\mathrm{H}_{2}$ photoproduction in Chlorella may differ from that of Chlamydomonas.

In a previous study, the most well-known mi- 
croalga with high $\mathrm{H}_{2}$ production was $C$. reinhardtii, which accumulates $\mathrm{H}_{2}$ at the rate of approximately $100-270 \mathrm{ml} / 1$ with $9-20 \mathrm{mg} / 1$ chlorophyll content $^{3,8}$. In this study, C. sorokiniana KU204 showed the highest $\mathrm{H}_{2}$-producing capacity $\left(1.30 \mathrm{ml} \mathrm{l}^{-1} \mathrm{~h}^{-1}\right)$ and accumulated up to $89.64 \mathrm{ml} / 1$ under simultaneous N-limitation and S-deprivation containing a chlorophyll content of 5-6 mg/l. If we assume that C. sorokiniana KU204 has a chlorophyll content of $10-12 \mathrm{mg} / \mathrm{l}$, this alga can produce $179.28 \mathrm{ml} / 1$ of $\mathrm{H}_{2}$. As C. sorokiniana has strong adaptability to local growing conditions and an extremely rapid growth rate, it is widely utilized on a large scale production. The increased $\mathrm{H}_{2}$ production of $C$. sorokiniana KU204 exposed to simultaneous N-limitation and $\mathrm{S}$-deprivation suggests then that this microalga has the potential to become a candidate for industrial $\mathrm{H}_{2}$ production.

In conclusion, from morphological characters and 18S rDNA sequence analysis, the six genera of the algae samples were identified as Chlamydomonas, Chlorella, Coelastrella, Micractinium, Monoraphidium, and Scenedesmus. The ITS sequences were successfully used to identify the species of the algae strains. Most tested green algal strains had the ability to generate $\mathrm{H}_{2}$ when exposed to S-deprivation. In addition, Chlorella lewinii, Micractinium sp., Coelastrella sp., and Monoraphidium sp. were found in this work as novel $\mathrm{H}_{2}$-producing strains. When the cells were grown under simultaneous $\mathrm{N}$-limitation and S-deprivation, $\mathrm{H}_{2}$ photoproduction increased in most tested strains of Chlorella and in all the strains of Chlamydomonas. However, this interesting result was not found in any strain of Coelastrella, Micractinium or Scenedesmus. The $C$. sorokiniana strain KU204 could accumulate significant $\mathrm{H}_{2}$ under simultaneous N-limitation and $\mathrm{S}$-deprivation. Thus further research efforts are required to optimize cultivation conditions. This study also suggests that conditions of simultaneous $\mathrm{N}$-limitation and S-deprivation could be an alternative method for enhancing the $\mathrm{H}_{2}$-producing ability in some microalgae such as Chlorella and Chlamydomonas.

Acknowledgements: This work was financially supported by the program Strategic Scholarships for Frontier Research Network for the Joint Ph.D. Programme Thai Doctoral degree, the Commission on Higher Education, and a research scholarship for a Ph.D. thesis from the Ministry of energy, Thailand. We would like to thank the Institute of Oceanology, Chinese Academy of Sciences for carrying out part of the research work.

\section{REFERENCES}

1. Mathews J, Wang G (2009) Metabolic pathway engineering for enhanced biohydrogen production. Int $J$ Hydrogen Energ 34, 7404-16.

2. Gaffron $\mathrm{H}$ (1939) Reduction of $\mathrm{CO}_{2}$ with $\mathrm{H}_{2}$ in green plants. Nature 143, 204-5.

3. Melis A, Zhang L, Forestier M, Ghirardi ML, Seibert M (2000) Sustained photobiological hydrogen gas production upon reversible inactivation of oxygen evolution in the green alga Chlamydomonas reinhardtii. Plant Physiol 122, 127-35.

4. Batyrova KA, Tsygankov AA, Kosourov SN (2012) Sustained hydrogen photoproduction by phosphorus-deprived Chlamydomonas reinhardtii cultures. Int J Hydrogen Energ 37, 8834-9.

5. Philipps G, Happe T, Hemschemeier A (2012) Nitrogen deprivation results in photosynthetic hydrogen production in Chlamydomonas reinhardtii. Planta 235, 729-45.

6. He ML, Li L, Zhang LT, Liu JG (2012) The enhancement of hydrogen photoproduction in Chlorella protothecoides exposed to nitrogen limitation and sulfur deprivation. Int J Hydrogen Energ 37, 16903-15.

7. Maneeruttanarungroj C, Lindblad P, Incharoensakdi A (2010) A newly isolated green alga, Tetraspora sp. CU2551, from Thailand with efficient hydrogen production. Int J Hydrogen Energ 35, 13193-9.

8. Melis A (2007) Photosynthetic $\mathrm{H}_{2}$ metabolism in Chlamydomonas reinhardtii (unicellular green algae). Planta 226, 1075-86.

9. Zhang LT, He ML, Liu JG (2014) The enhancement mechanism of hydrogen photoproduction in Chlorella protothecoides under nitrogen limitation and sulfur deprivation. Int J Hydrogen Energ 39, 8969-76.

10. Hoober JK (1989) The Chlamydomonas sourcebook. In: Harris EH (ed) A Comprehensive Guide to Biology and Laboratory Use, Academic Press, San Diego, pp 1503-4.

11. John DM, Whitton BA, Brook AJ (2002) The freshwater algal flora of the British Isles. An identification guide to freshwater and terrestrial algae, Cambridge Univ Press, Cambridge, p 702.

12. Timmins M, Thomas-Hall SR, Darling A, Zhang E, Hankamer B, Marx UC, Schenk PM (2009) Phylogenetic and molecular analysis of hydrogen-producing green algae. $J$ Exp Bot 60, 1691-702.

13. Tamura K, Peterson D, Peterson N, Stecher G, Nei M, Kumar S (2012) MEGA5: molecular evolutionary genetics analysis using maximum likelihood, evolutionary distance, and maximum parsimony methods. Mol Biol Evol 28, 2731-9.

14. He ML, Li L, Liu JG (2012) Isolation of wild microalgae from natural water bodies for high hydrogen producing strains. Int J Hydrogen Energ 37, 4046-56.

15. Liu JG, Bukatin VE, Tsygankov AA (2006) Light 
energy conversion into $\mathrm{H}_{2}$ by Anabaena variabilis mutant PK84 dense cultures exposed to nitrogen limitations. Int J Hydrogen Energ 31, 1591-6.

16. Qiao H, Wang G, Zhang X (2009) Isolation and characterization of chlorella sorokiniana GXNNO (Chlorophyta) with the properties of heterotrophic and microaerobic growth. J Phycol 45, 1153-62.

17. Grossman A, Takahashi H (2001) Macronutrient utilization by photosynthetic eukaryotes and the fabric of interactions. Annu Rev Plant Physiol 52, 163-210.

18. Hase E, Morimura Y, Mihara S, Tamiya H (1958) The role of sulfur in the cell division of Chlorella. Arch Mikrobiol 31, 87-95.

19. Plumley FG, Schmidt GW (1989) Nitrogen-dependent regulation of photosynthetic gene expression. Proc Natl Acad Sci USA 86, 2678-82.

20. Wykoff DD, Davies JP, Melis A, Grossman AR (1998) The regulation of photosynthetic electron transport during nutrient deprivation in Chlamydomonas reinhardtii. Plant Physiol 117, 129-39.

21. Brooks A (1985) Effects of phosphorus nutrition on ribulose-1,5-bisphosphate carboxylase activation, photosynthetic quantum yield and amounts of some Calvin-cycle metabolites in spinach leaves. Aust $J$ Plant Physiol 13, 221-37.

22. Jacob J, Lawlor DW (1993) In vivo photosynthetic electron transport does not limit photosynthetic capacity in phosphate deficient sunflower and maize leaves. Plant Cell Environ 16, 785-95.

23. Dietz KJ, Heilos L (1990) Carbon metabolism in spinach leaves as affected by leaf age and phosphorus and sulfur nutrition. Plant Physiol 93, 1219-25.

24. Plesnicar M, Kastori R, Petrovic N, Pankovic D (1994) Photosynthesis and chlorophyll fluorescence in sunflower (Helianthus annuus L.) leaves is affected by phosphorus nutrition. $J$ Exp Bot 45, 919-24.

25. Tamburic B, Zemichael FW, Maitland CM, Hellgardt K (2010) Parameters affecting the growth and hydrogen production of the green alga Chlamydomonas reinhardtii. Int J Hydrogen Energ 36, 7872-6. 